\title{
A multi-disciplinary model of survivorship care following definitive chemoradiation for anal cancer
}

\author{
Marissa B. Savoie ${ }^{1}$, Angela Laffan², Cristina Brickman³ , Bevin Daniels ${ }^{4}$, Anna Levin², ${ }^{2,5}$ Tami Rowen ${ }^{6}$, James Smith ${ }^{7}$, \\ Erin L. Van Blarigan ${ }^{2,7,8}$, Thomas A. Hope ${ }^{2,9}$, J. Michael Berry-Lawhorn ${ }^{10}$, Mekhail Anwar ${ }^{2,11}$ and \\ Katherine Van Loon ${ }^{2,10^{*}}$ iD
}

\begin{abstract}
Following definitive chemoradiation for anal squamous cell carcinoma (ASCC), patients face a variety of chronic issues including: bowel dysfunction, accelerated bone loss, sexual dysfunction, and psychosocial distress. The increasing incidence of this disease, high cure rates, and significant long-term sequelae warrant increased focus on optimal survivorship care following definitive chemoradiation. In order to establish our survivorship care model for ASCC patients, a multi-disciplinary team of experts performed a comprehensive literature review and summarized best practices for the multi-disciplinary management of this unique patient population. We reviewed principle domains of our survivorship approach: (1) management of chronic toxicities; (2) sexual health; (3) HIV management in affected patients; (4) psychosocial wellbeing; and (5) surveillance for disease recurrence and survivorship care delivery. We provide recommendations for the optimization of survivorship care for ASCC patients can through a multi-disciplinary approach that supports physical and psychological wellness.
\end{abstract}

Keywords: Anal cancer, Survivorship, Toxicity, Surveillance

\section{Background}

Anal squamous cell carcinoma (ASCC) is a rare cancer, with only 8580 cases diagnosed in the United States annually. However, the incidence has steadily increased at a rate of $2.2 \%$ per year over the last 10 years [1]. ASCC is mediated by the human papilloma virus (HPV) in $85-95 \%$ of cases [2-4]. Accordingly, risk factors for ASCC largely overlap with risk factors for HPV infection, including: human immunodeficiency virus (HIV) infection, solid-organ transplantation, multiple sexual partners, anal-receptive intercourse, anal warts, history of cervical, vulvar, or vaginal carcinoma, chronic immune suppression, and cigarette smoking $[5,6]$. However, this disease also occurs in the absence of immunocompromise and numerous sexual partners. While ASCC is rare, the prevalence of anal HPV

\footnotetext{
* Correspondence: katherine.vanloon@ucsfedu

${ }^{2}$ Helen Diller Family Comprehensive Cancer Center, University of California, San Francisco, USA

${ }^{10}$ Department of Medicine, Division of Hematology/Oncology, University of California, San Francisco, USA

Full list of author information is available at the end of the article
}

in women is comparable to that of cervical HPV in women [7], and HPV transmission can occur during vaginal intercourse due to contamination of the entire perineal area. In fact, HIV-negative females without identified high-risk behaviors are over-represented in the rising incidence of this disease $[8,9]$.

Intensive radiation with concurrent 5-flurouracil and mitomycin is the standard treatment for locoregional ASCC [10-12]. The advent of more advanced radiotherapy techniques, such as intensity-modulated radiation therapy (IMRT), has allowed for more focused radiation and is associated with lower rates of chronic toxicities [13]. Given the enhanced ability to tailor radiation treatment with IMRT, there is an increased emphasis on understanding long-term side effects so that these can be taken into account during radiation planning. However late toxicity data is sparse, reflecting the paucity of long-term data collection in therapeutic trials $[14,15]$.

Cure rates exceed $80 \%$ for the $90 \%$ for patients diagnosed with locoregional disease [1], and the majority of patients diagnosed with ASCC will become long-term 
survivors. However, even after being rendered diseasefree, patients face myriad treatment-related sequelae over subsequent decades. Specifically, ASCC survivors report a high prevalence of chronic toxicities including: sexual dysfunction, bowel dysfunction, accelerated bone loss, cognitive changes, and fatigue [16]. Additionally, care for ASCC survivors is wrought with issues related to social isolation due to perceptions of stigma [17].

The University of California, San Francisco (UCSF) is home to the Anal Neoplasia Clinic, which was founded in 1991 to address increased rates of anal dysplasia, a precursor of ASCC, observed in people living with HIV (PLWH) [18]. This clinic serves to diagnose anal dysplasia and also to monitor for ASCC recurrence in survivors. Patients from the San Francisco and Oakland region are more likely to have in-situ tumors than patients from other areas of California; this has been attributed in part to the accessibility of successful screening efforts [19]. Given higher rates of HIV infection in the San Francisco Bay Area and increased rates of curable disease compared to national populations, our institution cares for a high volume of ASCC survivors.

In order to establish our survivorship care model for ASCC patients, a multi-disciplinary team of experts in the Gastrointestinal Oncology Survivorship practice at our institution performed a comprehensive literature review of the survivorship issues and summarized best practices for the management of this unique patient population. Herein, we describe our multi-disciplinary approach to caring for patients with ASCC following curative treatment. The principle components of this approach include: (1) management of chronic toxicities; (2) sexual health; (3) HIV management in affected patients; (4) psychosocial wellbeing; and (5) surveillance for disease recurrence and survivorship care delivery.

\section{Management of chronic toxicities Bowel dysfunction}

CRT for ASCC involves a variable amount of radiation delivered to the rectum, large and small intestines. While guidelines exist governing the maximum recommended dose for bowel, tumor stage, bulk, proximity to bowel, and variations in patient anatomy result in significant heterogeneity in bowel exposure to radiation. Not unexpectedly, patients commonly experience bowel dysfunction following CRT with variable onset, degree and duration, ranging from months to years. Long-term toxicity data from clinical trials of chemotherapy with 3D radiation and IMRT report moderate or higher gastrointestinal toxicity rates of approximately $10 \%$ [11] and $8-10 \%[20,21]$ respectively (Table 1).

Among cancer patients of various tumor types, approximately half of patients who receive treatment with pelvic radiation report their quality of life following treatment is compromised by gastrointestinal symptoms $>3$ months after completion of treatment [25-27]. These patients report that fecal urgency, incontinence, and tenesmus impede quality of life by causing emotional distress and disruptions to social function [26]. One study demonstrated that $29 \%$ of ASCC survivors reported changes in bowel patterns [16], and another demonstrated that 26\% of patients report the effect of diarrhea on quality of life as "quite a bit or higher" [28].

Diarrhea is the most cited gastrointestinal concern that impacts quality of life following treatment for ASCC [21, 25, 29-35]. Diarrhea can alternate with constipation and be accompanied by abdominal cramping, rectal bleeding, or pain $[25,30,34]$. Management of diarrhea can range from dietary modifications and use anti-diarrheal medications to procedures performed by specialists which target the site of tissue injury [36]. Fecal urgency is often noted; however, this is likely underreported in the literature as current toxicity scales do not allow for categorization of urgency or tenesmus as a complaint independent from proctitis [22, 24]. Several studies of late radiation toxicity in ASCC patients indicate that severity of bowel dysfunction is stable in the years following CRT [31,37], indicating the potential for persistent, rather than resolving, late bowel toxicities.

In a patient who presents with diarrhea and hematochezia after CRT for ASCC, colonoscopy or high-resolution anoscopy (HRA) and/or CT or MRI may be warranted to differentiate chronic radiation enteritis or proctitis from other causes. In the setting of chronic radiation enteritis,

Table 1 Rates of late (> 90 days after last chemoradiation therapy) gastrointestinal toxicity among anal cancer patients

\begin{tabular}{|c|c|c|c|c|}
\hline Study & Grading system & Grade 1 & Grade $2+$ & Grade 3+ \\
\hline Mitra et al. [21] 2017 (IMRT) & CTCAE v4.0 [22] & $37 \%$ & $10 \%$ & $2 \%$ \\
\hline Mitchell et al. [20] 2014 (IMRT) & CTCAE v4.0 [22] & Not given & $8 \%$ & $3 \%$ \\
\hline Tomaszewski et al. [23] 2012 & CTCAE v4.0 [22] & Not given & Not given & $3 \%$ \\
\hline Gunderson et al. [12] 2012 & $\begin{array}{l}\text { RTOG and EORTC } \\
\text { toxicity criteria [24] }\end{array}$ & Not given & Not given & $2 \%$ \\
\hline Ajani et al. [11] 2008 & $\begin{array}{l}\text { RTOG and EORTC } \\
\text { toxicity criteria [24] }\end{array}$ & $16 \%$ & $8 \%$ & $3 \%$ \\
\hline
\end{tabular}

IMRT intensity-modulated radiation therapy, CTCAE common terminology criteria for adverse events, RTOG Radiation Therapy Oncology Group, EORTC European Organisation for Research and Treatment of Cancer 
biopsies demonstrate increased friability and telangiectasias, consistent with ischemic injury, and CT/MRI demonstrate bowel inflammation with hyperenhancement and bowel thickening [25]. The presence of peri-anal telangiectasias on external exam (Fig. 1) may signal providers to consider similar internal pathology. Mainstays of managing chronic radiation enteritis include antidiarrheal medicines and adherence to a lactose-free, low-fiber, and low-fat diet [38-40]; steroids and pain medication can be considered with initial presentation. Surgery to mitigate fibrosis, adhesions, or fistulae secondary to radiation enteritis is a last recourse, as short bowel syndrome is a potential complication [41-43].

While radiation enteritis involves damage to the intestines, late proctitis is a manifestation of ischemic radiation injury to the rectum and may present as diarrhea, bleeding, tenesmus, and/or urgency years after radiation exposure $[44,45]$. After infectious etiology has been excluded by history and/or cultures, a rectal biopsy should be considered; the findings of friability and telangiectasias are nonspecific for radiation proctitis. Sucralfate enemas have been shown to decrease rectal bleeding [46-50]. Directed interventions such as argon plasma coagulation and formalin treatment to the rectal site of injury can be utilized to quell bleeding although these interventions carry risks for fistula formation [51-61]. Hyperbaric oxygen treatment has been shown improve radiation proctitis symptoms and increase probability of healing $[62,63]$. This was shown among patients who had radiation proctitis refractory to other treatments for $>3$ months, suggesting that hyperbaric oxygen should be reserved as an intervention for refractory symptoms [63].

Given the variable latency of late radiation bowel dysfunction, a new presentation of inflammatory bowel disease, infectious gastroenteritis, or acute proctitis secondary to sexually transmitted infection should also be considered.

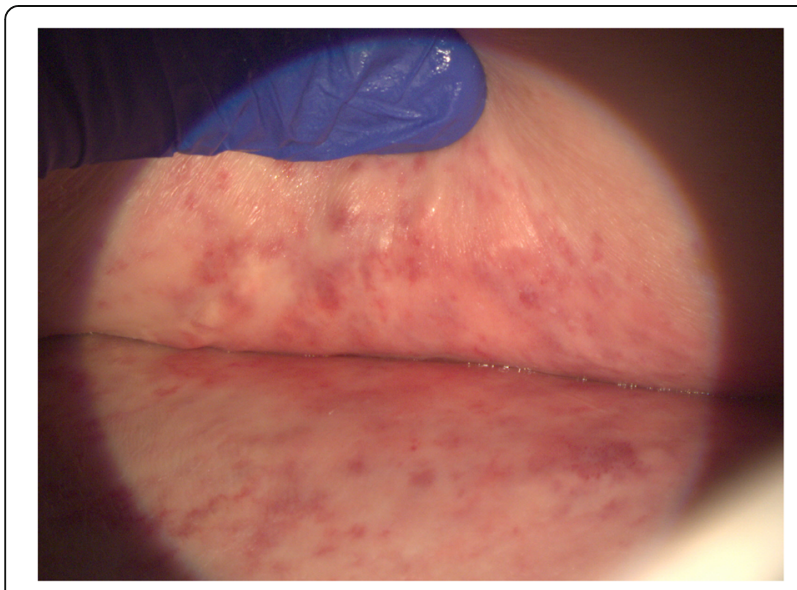

Fig. 1 Perianal telangiectasias. Perianal telangiectasias seen on the skin after radiation therapy for anal squamous cell carcinoma
Other causes of bowel dysfunction related to pelvic radiation include bacterial overgrowth and fibrosis. If bacterial overgrowth is suspected due to history of chronic malabsorptive diarrhea in the absence of other identified causes, carbohydrate breath test may aid in diagnosis but is limited by low sensitivity [64]. Potential interventions for bacterial overgrowth include antibiotics, with rifaximin as the preferred initial agent [64]. Like chronic radiation enteritis, generalized gastrointestinal radiation toxicities can be managed with trial(s) of lactose-free and/or a BRAT diet [25, 27, 65].

\section{Accelerated bone degeneration}

As a key component to curative treatment for ASCC, external beam radiotherapy targets the primary tumor and involved nodes, as well as areas at high risk for subclinical or microscopic disease. Innovations over the last two decades in radiotherapy delivery have moved from 2D or 3D techniques to highly conformal IMRT. This allows personalized delivery with maximum dosing to key areas (gross or visible tumor) and elective dosing to at-risk areas. Notably, this customized sculpting keeps high-dose radiation away from critical bone regions [66], such as the femoral heads, with the tradeoff of a larger area of bone exposed to lower dose radiation.

Pelvic insufficiency fractures (PIFs) are the most commonly discussed chronic bone toxicity of pelvic radiation $[67,68]$; however, osteoradionecrosis and osteomyelitis are rarer, late complications of pelvic radiation [69, 70]. PIFs following pelvic radiation most often occur in the sacrum, pubic symphysis, or pubic rami $[67,71,72]$. While the limited studies evaluating the late effects of CRT in ASCC patients have not found adequate evidence to determine a consensus around risk of PIFs for these patients, one study noted a $9.3 \%$ incidence rate of PIFs in ASCC patients treated with IMRT with a median follow-up interval of 3.1 years (Table 2) [72]. Higher radiation dose, post-menopausal status in females, low BMI, and prior osteoporosis have been observed as risk factors for PIF in patients who have received pelvic radiation [72, 73, 75, 77, 83]. Patients with treated HIV have an elevated risk for decreased bone mineral density in the hip and lumbar spine region at baseline and they may be at a heightened risk for PIF [85]. Figure 2 provides an example of bilateral sacral insufficiency fractures in a patient who received pelvic radiation for ASCC.

PIFs are not uncommon among ASCC patients following CRT; however, the complications from these fractures are usually self-limited. The clinical presentation of PIF rarely requires hospitalization or extensive intervention beyond pain management $[78,79,81,83,86,87]$. Considering these findings, screening for osteopenia or osteoporosis should be performed following completion of CRT with a dual-energy x-ray absorptiometry (DEXA) scan. Supplementation of 
Table 2 Summary of studies measuring incidence of pelvic insufficiency fractures (PIFs) among cancer patients receiving pelvic radiation therapy

\begin{tabular}{|c|c|c|c|c|c|c|c|}
\hline Study & Era & No. patients & $\begin{array}{l}\text { Median time to } \\
\text { fracture/total follow-up }\end{array}$ & $\begin{array}{l}\text { Median total } \\
\text { dose (Gray) }\end{array}$ & Disease site & $\begin{array}{l}\text { Study } \\
\text { Incidence }\end{array}$ & $\begin{array}{l}\text { 5-year actuarial } \\
\text { incidence }^{b}\end{array}$ \\
\hline \multirow[t]{2}{*}{$\begin{array}{l}\text { Bazire et al. [72] } \\
2017\end{array}$} & \multirow[t]{2}{*}{$2007-2014$} & \multirow[t]{2}{*}{341} & \multirow[t]{2}{*}{$11 \mathrm{mo} . / 38 \mathrm{mo}}$. & \multirow[t]{2}{*}{50.3} & \multirow[t]{2}{*}{$\begin{array}{l}52 \% \text { cervical } 32 \% \\
\text { endometrial } 16 \% \text { anal }\end{array}$} & $\begin{array}{l}4.4 \% \\
\text { Radiographic } \\
\text { (R) }\end{array}$ & \multirow[t]{2}{*}{ Not given } \\
\hline & & & & & & $\begin{array}{l}3.2 \% \\
\text { Symptomatic } \\
\text { (S) }\end{array}$ & \\
\hline \multirow{2}{*}{$\begin{array}{l}\text { Shih et al. [73] } \\
2013\end{array}$} & \multirow{2}{*}{$\begin{array}{l}2000-2008 \\
37 \% \text { IMRT }\end{array}$} & \multirow[t]{2}{*}{222} & \multirow[t]{2}{*}{$12 \mathrm{mo} . / 47 \mathrm{mo}}$. & \multirow[t]{2}{*}{50.4} & \multirow{2}{*}{$\begin{array}{l}65 \% \text { endometrial 35\% } \\
\text { cervical }\end{array}$} & $5.0 \%(R)$ & \multirow[t]{2}{*}{$5.1 \%(R)$} \\
\hline & & & & & & $3.2 \%(S)$ & \\
\hline \multirow{2}{*}{$\begin{array}{l}\text { Uezono et al. } \\
\text { [74] } 2013\end{array}$} & \multirow[t]{2}{*}{ 2003-2009 } & \multirow[t]{2}{*}{99} & \multirow[t]{2}{*}{14 mo./21 mo. } & \multirow[t]{2}{*}{50.4} & \multirow[t]{2}{*}{ cervical } & $33 \%(\mathrm{R})$ & \multirow[t]{2}{*}{$63 \%(R)$} \\
\hline & & & & & & $20 \%(S)$ & \\
\hline $\begin{array}{l}\text { Kim et al. [75] } \\
2012\end{array}$ & 1998-2007 & 492 & 46 mo./42 mo. & 50.4 & rectal & $\begin{array}{l}7.1 \% \text { sacral } \\
\text { fracture }(\mathrm{R})\end{array}$ & Not given \\
\hline \multirow{2}{*}{$\begin{array}{l}\text { Tokumaru et al. } \\
\text { [76] } 2012\end{array}$} & \multirow[t]{2}{*}{ 2004-2007 } & \multirow[t]{2}{*}{59} & \multirow[t]{2}{*}{ not given/24 mo. } & \multirow[t]{2}{*}{49} & \multirow[t]{2}{*}{ cervical } & $36 \%(R)$ & \multirow[t]{2}{*}{ Not given } \\
\hline & & & & & & $15 \%(S)$ & \\
\hline \multirow{2}{*}{$\begin{array}{l}\text { Schmeler et al. } \\
\text { [77] } 2010\end{array}$} & \multirow{2}{*}{$\begin{array}{l}\text { 2001-2006 } \\
3 \% \text { IMRT }\end{array}$} & \multirow[t]{2}{*}{300} & \multirow[t]{2}{*}{14 mo./21 mo. } & \multirow[t]{2}{*}{45} & \multirow[t]{2}{*}{ cervical } & $9.7 \%(\mathrm{R})$ & Not given \\
\hline & & & & & & $4.3 \%(S)$ & \\
\hline $\begin{array}{l}\text { Herman et al. } \\
\text { [78] } 2009\end{array}$ & 1989-2004 & 562 & 17 mo./49 mo. & 45 & rectal & $\begin{array}{l}2.7 \% \text { sacral } \\
\text { fracture (R) }\end{array}$ & Not given \\
\hline & & & & & & $\begin{array}{l}1.2 \% \text { sacral } \\
\text { fracture }(\mathrm{S})\end{array}$ & \\
\hline Oh et al. [79] & 1998-2005 & 557 & 13 mo./30 mo. & 45 & cervical & $15 \%(R)$ & $20 \%(R)$ \\
\hline & & & & & & $8.6 \%(S)$ & $11 \%(S)$ \\
\hline Kwon et al. [80] & 1998-2005 & 510 & 17 mo./14 mo. & 50.4 & cervical & $20 \%(R)$ & $45 \%(R)$ \\
\hline & & & & & & $8.4 \%(\mathrm{~S})$ & \\
\hline $\begin{array}{l}\text { Ikushima et al. } \\
\text { [81] } 2006\end{array}$ & 1993-2004 & 158 & 6 mo./43 mo. & 45 & $\begin{array}{l}96 \% \text { cervical } 4 \% \\
\text { endometrial }\end{array}$ & $11 \%(S)$ & $13 \%(S)$ \\
\hline $\begin{array}{l}\text { Baxter et al. } \\
\text { [82] } 2005\end{array}$ & 1986-1999 & $\begin{array}{l}399 \text { women } \\
\text { age } 65+\end{array}$ & not given/47 mo. & Not given & anal & $\begin{array}{l}14 \% \text { (unclear } \\
\mathrm{R} / \mathrm{S} \text { ) }\end{array}$ & $\begin{array}{l}\text { 14\% (unclear R/ } \\
\text { S) }\end{array}$ \\
\hline Ogino et al. & 1983-1998 & 335 post- & 8 mo./39 mo. & 49.4 & cervical & $17 \%(R)$ & $18 \%(S)$ \\
\hline & & & & & & $14 \%(S)$ & \\
\hline $\begin{array}{l}\text { Tai et al. [84] } \\
2000\end{array}$ & 1991-1995 & 336 & 11 mo./29 mo. & Not given & endometrial vaginal & $4.8 \%(S)$ & $2.1 \%(\mathrm{~S})$ \\
\hline
\end{tabular}

Incidence calculated over variable study period

$\mathrm{b}_{5}$-year actuarial incidence calculated with Kaplan Meier analysis

vitamin D and calcium, oral bisphosphonates, or anabolic agents may be warranted, as recommended by ageappropriate preventative care recommendations and the National Comprehensive Cancer Network (NCCN) Guidelines for Oncology Survivorship [88].

\section{Pelvic floor dysfunction}

Radiation treatment to the pelvis and anus can affect pelvic floor muscles, fascia, and nerves, resulting in pelvic floor dysfunction. Specifically, significant pelvic floor muscle weakness is common after pelvic radiation [89], and myofascial trigger points and increased muscle tension can cause pain. Research on pelvic floor physical therapy after cancer is largely derived from gynecologic and colorectal cancer patients and consistently demonstrates improvements in pelvic floor function [90, 91]. Extrapolating from existing literature, physical therapy directed towards the pelvic floor can play an important role in recovery and help improve quality of life after radiation treatment, particularly for survivors who present with fecal and/or urinary incontinence, dyspareunia, or sexual dysfunction.

Impairments in pelvic floor muscle strength, coordination and tone caused by radiation can be successfully treated with neuromuscular re-education, biofeedback, and electrical stimulation. Internal and/or external manual treatments, such as myofascial release, connective tissue manipulation, and joint mobilization to the pelvis, spine and hips, may be used to treat pelvic pain. Vaginal 


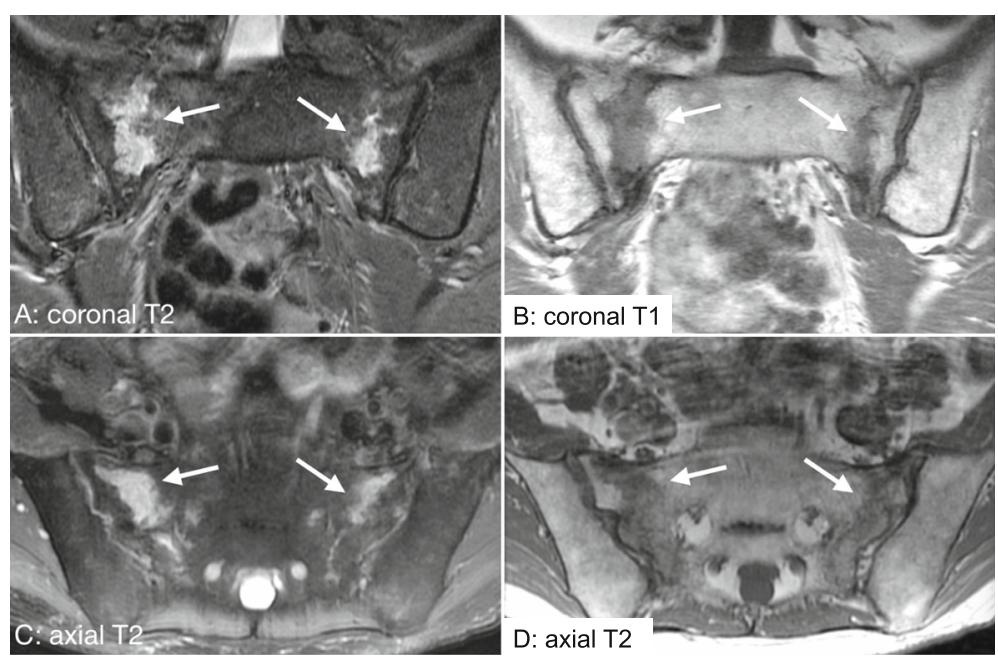

Fig. 2 Pelvic insufficiency fracture. Coronal T1 (Image b), coronal T2 (Image a) and axial T2 (Image c, d) weighted images demonstrating high T2 signal bilaterally along the sacroiliac joints consistent with bilateral sacral insufficiency fractures

and/or anal dilation therapy is commonly incorporated as a component of pelvic rehabilitation programs to treat canal stenosis and dyspareunia. Finally, due to the impact of deconditioning and fatigue following cancer treatment, patients may benefit from education on cardiovascular exercise and activity pacing; posture training; and core muscle strengthening. Treatment plans are individualized based on examination findings and patient goals and typically range from four to twelve sessions.

\section{Sexual health}

\section{Sexual dysfunction in female survivors}

More than half of women with ASCC will endure some form of sexual dysfunction after CRT, including effects on desire, arousal, orgasm and/or pain [35, 92]. A significant number of women who were previously sexually active report becoming inactive following treatment [93-95]. Because chemotherapy targets rapidly dividing cells and is given systemically, it directly targets the ovaries and may lead to decreased estradiol and symptoms of early menopause, which include but are not limited to: vaginal dryness; hot flushes; and decreased libido [93]. Some women will recover from chemotherapy-induced menopause, though this is highly dependent on age, and the existing data is largely derived from breast or gynecologic cancer patients [96, 97].

Additionally, pelvic radiation has short term consequences including inflammation, erythema, and desquamation that can cause significant vaginal pain and dyspareunia. Over time, however, the long-term effects of pelvic radiotherapy will result in decreased oxygenation of the tissue, leading to fibrosis, stenosis and adhesions that can leave the vagina shorter, narrower, and less elastic [92]. Studies have reported up to $79 \%$ prevalence of grade 1-3 vaginal stenosis in women after definitive CRT for ASCC, therefore early intervention is imperative [98]. Female patients should be referred to gynecology for early evaluation and discussion of gynecological and sexual health after CRT, ideally with initiation of vaginal dilator therapy within four to 8 weeks after completion of therapy, when indicated.

The mainstays of prevention of sexual health toxicities following treatment for ASCC have focused on vaginal dilator therapy. The premise is that by manually dilating the vagina with a phallic shaped device, women will be able to prevent many of long-term toxicities that lead to vaginal shortening, fibrosis, and stenosis which cause dyspareunia. Unfortunately, despite dilators being promoted in a majority of survivorship programs, the data supporting their use is extremely limited. Indeed, a 2014 Cochrane review found "there is no reliable evidence to show that routine, regular vaginal dilation during radiotherapy treatment prevents stenosis or improves quality of life" [99]. A significant limitation in the majority of vaginal dilator studies is the lack of control group and lack of compliance $[100,101]$. Additionally there is no uniform practice or evidence-based guideline for when to initiate dilator therapy or for how often or how long to continue [101]. Further research is necessary to determine who derives benefit from dilator use as well as optimal strategies to prevent radiation toxicity.

While the majority of literature focuses on vaginal dilator therapy to prevent local radiation toxicity, recently there is a new focus on ovarian suppression at the time of treatment to prevent menopause induced by CRT. Despite mixed early data on ovarian suppression during chemotherapy [102], a recent randomized controlled trial of ovarian suppression in breast cancer patients showed that patients who received gonadotropin-releasing hormone 
agonist had reduced rates of premature menopause without evidence of worsened disease-related outcomes [103]. Additionally, studies are actively investigating multimodal treatments that focus on the psychological effects of treatment, which also have a significant effect on sexual health and can affect the most critical domains of desire and arousal [93]. Any intervention to improve sexual function should ensure that a comprehensive, multidisciplinary approach is employed, focusing on the psychology, endocrinology and physiology of sexual expression and satisfaction and addresses all domains of sexual health.

\section{Sexual dysfunction in male survivors}

Although data on sexual function in male survivors of ASCC is sparse, studies consistently demonstrate that male survivors have significantly impaired sexual function when compared to age and gender-matched controls [33, 34] and even compared to colorectal cancer survivors [16]. Extrapolating from the literature regarding men who have received external radiation therapy for prostate cancer, erectile dysfunction (ED), orgasmic dysfunction, and pain are the most common domains of sexual dysfunction for men following pelvic radiation [104]. Cross-sectional studies show ED likely affects most male ASCC survivors, regardless of age [16, 28, 29, 33, 35].

While it has been hypothesized that sexual dysfunction in males following treatment for ASCC is due to tumor fibrosis and pelvic radiation, a correlation has not been found between radiation dose and sexual dysfunction [35]. ED associated with pelvic radiation may be exacerbated by traditional risk factors for penile arterial insufficiency such as hypertension, hyperlipidemia, cigarette smoking, and diabetes mellitus [105-107]. Psychological distress and relationship strain experienced by ASCC survivors may also contribute to psychogenic ED [108, 109].

Phosphodiesterase type-5 inhibitors (PDE5is) are the general first line approach for treatment of ED, and some data supports the efficacy of PDE5is to treat ED associated with pelvic radiotherapy in cancer survivors [110-112]. PDE5is act as amplifiers of the normal erectile physiology and are dependent on intact libido, sexual stimulation, sensory pathways, and other myriad factors that must be present in normal erectile function.

PDE5i use in patients with cardiovascular disease requires consideration of cardiovascular risk and concurrent medications or substance use (nitrate-containing medications and amyl nitrate inhalers are absolutely contraindicated). Patients with high-risk cardiovascular disease should have their cardiovascular status stabilized prior to resuming sexual activity [113]. Options for second line therapies for ED not responsive to PDE5is include vacuum erectile devices, intracavernosal injections, and transurethral alprostadil. Use of a penile prosthesis may be efficacious as a third-line therapy. However, these indications have been developed in men without cancer, and efficacy in ASCC survivors or recipients of pelvic radiotherapy has not been well studied.

In addition to ED, cross-sectional studies of ASCC survivors note that fecal incontinence is a prominent treatment sequela. For patients who practice anal receptive intercourse (ARI), fecal incontinence might impede sexual function; however, the effect of ASCC treatment on ARI has not been previously studied. Consideration should be given to provide advice regarding safer sex practices, including lubricant usage, and screening for sexually transmitted infections.

\section{HIV management}

Infection with HIV is one of the strongest risk factors for ASCC [114-117]. Fortunately, survival for individuals with HIV on anti-retroviral therapy (ART) is comparable to that of individuals without HIV [118-120]. Treatment is similar to that of the general population, although special attention is needed to evaluate the adequacy of ART and to determine whether additional antimicrobial prophylaxis is indicated.

Current standards dictate that the HIV viral load of patients stable on ART should be monitored at least every 6 months to ensure that it remains undetectable [121]. Whether more frequent testing is needed during or following exposure to chemotherapy is unknown, but an approach that includes monitoring once a month for the first 3 months of chemotherapy and every 3 months thereafter has been proposed [122, 123]. This approach is reasonable given that patients may have suboptimal ART adherence during chemotherapy, drug-drug-interactions may decrease ART effectiveness, and the identification of early virologic failure can prevent complications.

PLWH who are not on ART are at risk for infections associated with depleted cell-mediated immunity. Guidelines recommend antimicrobial prophylaxis against such opportunistic infections based on the number of remaining CD4 positive T-lymphocytes (CD4+ T-cells) in circulation [124]. These guidelines should be followed for PLWH who are ART-naive and about to initiate chemotherapy, with anticipation of decreases in CD4+ T-cells below the threshold for which prophylaxis related to HIV infection is recommended. It is unclear, however, whether these decreases truly reflect impaired cell-mediated immunity, and hence whether prophylaxis is warranted in patients in whom CD4+ T-cell counts are preserved and viral load are suppressed up until the initiation of CRT. Despite this, monitoring of and initiation of prophylaxis depending on CD4+ T-cell count is recommended by experts, especially since it is reasonably tolerated and easy to administer [122, 123]. Additional prophylaxis recommendations specific to individual chemotherapy regimens are centered around 
degree and duration of neutropenia; however, this is generally unnecessary with ASCC treatment during which prolonged neutropenia is uncommon.

\section{Psychosocial wellbeing}

NCCN guidelines recommend routine screening to assess the level and nature of emotional distress in all cancer survivors [125]. These guidelines provide guidance about the timing of screening, highlight patient factors associated with distress, and suggest a framework for determining when and to whom to refer emotionally distressed patients [125]. Patients treated with combined CRT for ASCC have a high burden of dysfunction and long-term sequelae [33], consequently levels of anxiety are significantly higher when compared to the general population and health-related quality of life scores show significant impaired in quality of life [33]. Reluctance to disclose sensitive issues may impede optimal management of symptoms; therefore, direct questioning by providers regarding sensitive issues, including bowel function, sexual health, and psychosocial distress, may facilitate communication.

Even in the absence of a clinical event that would trigger distress, many patients will be affected by fear of cancer recurrence, which can persist even when risk of recurrence is low, and is associated with poorer quality of life $[126,127]$. At a center which offers psychooncology services, we routinely offer referrals for psychotherapy; however, for centers without onsite services, qualified therapist referrals can be found in mental health provider directories [128, 129]. Additionally, the Anal Cancer Foundation is a national non-profit which offers a peer-to-peer support program that can be accessed either online or in-person (Table 3) [131].

Because of the unique risk factors and treatments associated with their disease, ASCC patients may perceive social stigma and experience shame. An ASCC survivor must contend with societal views on HPV and on sexual behavior. As providers, we aim to demonstrate sensitivity and immediate responsiveness to any patient expressions of fear of stigma or of shame/guilt.

PLWH and men who have sex with men (MSM) already face stigma, which may be compounded by a diagnosis of ASCC. Patients from sexual and/or gender minorities may be less likely to share information with medical providers because of concerns about stigma or discrimination [132]. As medical providers, we make every effort to address the unique needs of our lesbian, gay, bisexual, transgender, and/or queer (LGBTQ) patients and to minimize health disparities in these populations. Interventions may include seeking education about sexual and social history-taking and taking steps that signal inclusiveness to patients, such as displaying LBGTQ-friendly signs or registering with the Gay and Lesbian Medical Association's Provider Directory
Table 3 Resources for providers and patients

Psychosocial support

- Qualified therapist referral: Search United States ZIP code to find local therapist certified by Psychology Today. www.psychologytoday. com/us

- Peer support: In-person, phone, online connection with another anal cancerpatient. https://www.analcancerfoundation.org/find-support/ patient-support/connect-with-a-peer/

Physical fitness and nutrition

- Exercise program: YMCA 12-week fitness program specialized for cancer survivors, including those with physical restrictions. Free or reduced cost. https://www.livestrong.org/ymca-search

- Evidence-based guidelines: The American Cancer Society has put forth guidelines on nutrition and diet for cancer survivors, including literature for clinicians [130] and patients. https://www.cancer.org/ health-care-professionals/american-cancer-society-prevention-early-detection-guidelines/nupa-guidelines-for-cancer-survivors.html

Disease surveillance

- High-resolution anoscopy: Search providers across the United States that offer high-resolution anoscopy. https://analcancerinfo.ucsf. edu/hra-provider-list

- Provider trainings in high-resolution anoscopy are offered worldwide by the International Anal Neoplasia Society and include continuing medical education credits. https://ians.wildapricot.org/HRACourse-Overview

[133]. It is also essential for providers to acknowledge and examine how our own beliefs and biases may influence our care for patients [134, 135].

\section{Surveillance practices and survivorship care delivery}

The short and long-term sequelae of definitive CRT are complex and require a multidisciplinary approach. At our institution, care of ASCC patients after successful completion of treatment is delivered in the context of a multidisciplinary survivorship clinic, with representation of clinicians from oncology, surgery, radiation oncology, anal dysplasia, primary care, infectious diseases, gynecology, nutrition, psycho-oncology, social work, urology, and other disciplines. Transgender individuals may also benefit from endocrinology consultation or specialists in transgender health to optimize safe hormone management. In a complex treatment paradigm requiring multiple health care providers, the oncology survivorship provider serves as a navigator, prioritizing subspecialist referrals and synthesizing recommendations from a variety of disciplines (Table 3 ).

The goals of survivorship care for patients with ASCC following completion of definitive CRT are summarized in Fig. 3. A typical encounter in our Survivorship Clinic aims to address the following:

1) Provision of a Survivorship Care Plan to the patient and primary care provider with clearly documented surveillance guidelines [136]; 


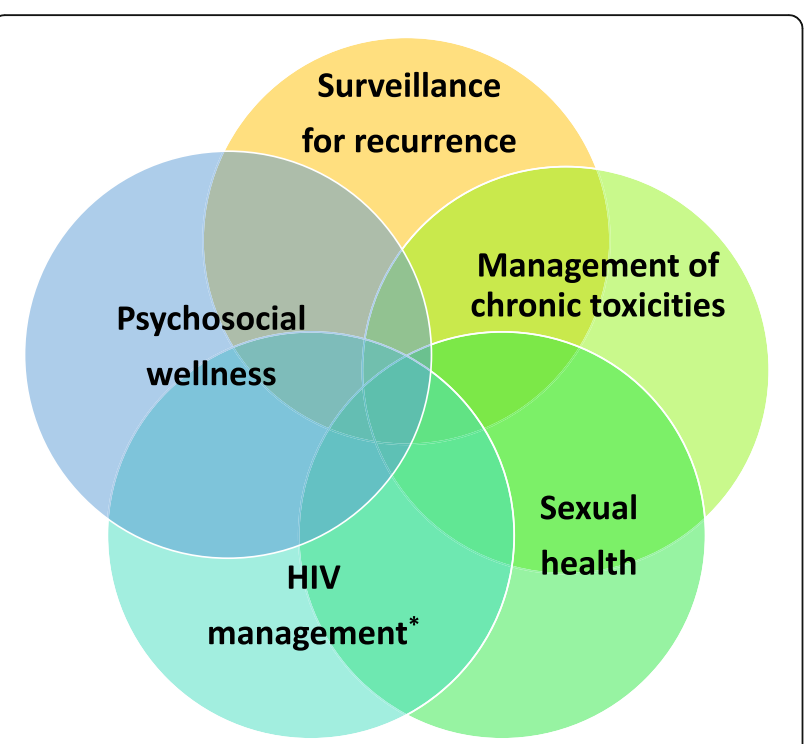

Fig. 3 Core domains of a multi-disciplinary model of survivorship care for patients with anal squamous cell carcinoma. *For HIV-infected patients only

2) Ensuring appropriate surveillance is performed;

3) Evaluation and management of acute and long-term toxicities; and

4) Promotion of risk-reduction strategies for cancer survivors including exercise [137], maintenance of a healthy weight, sleep hygiene, a plant-based diet, and avoidance of salt and refined foods [138]

Patients should be seen at frequent intervals post completion of CRT until resolution of acute side-effects of treatment. Acute toxicities secondary to definitive CRT have been documented to include: myelosuppression (50\%), skin toxicity (65\%), bowel dysfunction (17\%), constipation (3\%), fecal incontinence (9\%), proctitis (17\%), and fatigue (25\%) [139]. With resolution of acute toxicities, patients can then transition to clinical evaluations at three monthly intervals for surveillance imaging and screening for long-term toxicities.

Per NCCN guidelines, surveillance should include digital rectal exam and inguinal node palpation every three to 6 months for 5 years, proctoscopy or anoscopy every six to 12 months for 3 years, and CT scans of the chest, abdomen, and pelvis annually for 3years (Table 4) [141]. A $\mathrm{PET} / \mathrm{CT}$ with contrast performed at 6 months after completion of CRT has been shown to be the best predictor of a complete response to treatment [142] and is our standard institutional practice. Additionally, patients who have undergone pelvic radiation for HPV related cancers are at higher risk for developing subsequent cancers near the radiated sites [143, 144] and remain at higher risk for other HPV-related malignancies, especially cervical, oral, and pharyngeal cancers $[145,146]$. Thus, regular gynecologic visits with cervical cytology and dental examinations are recommended, though there is no consensus regarding the frequency and role for HPV testing in this population (Table 4).

The relationship between HPV and ASCC supports the use of HRA as surveillance modality for disease recurrence. The UCSF Anal Neoplasia Clinic employs an alternative screening model in which primary care providers perform HRA and anal cytology screening of our survivor population to evaluate for local recurrence. Most patients are able to undergo surveillance in the clinic, with HRA with biopsies of abnormal lesions performed at three or 4 month intervals (Table 4). HRA capacity is increasing through training workshops offered worldwide through the International Anal Neoplasia Society [147] and other organizations; however, there is still a need to better educate, inform, and train more providers to perform HRA.

Due to the myriad challenges ASCC survivors face, these patients derive significant benefit from a care model that facilitates navigation across a variety of medical specialties. Integration of the primary care provider (PCP) into survivorship care is imperative to ensure that patients resume age-appropriate health care maintenance and to ensure that the PCP is able to assume complete care for the patient. Survivorship care can be transitioned to the PCP during or after the surveillance period is complete.

\section{Conclusions}

In summary, a growing population of ASCC survivors faces a complex burden of physical and psychosocial sequelae.

Table 4 Survivorship care elements and intervals

\begin{tabular}{|c|c|c|c|c|c|c|c|c|c|c|c|c|c|}
\hline Months since end of treatment & $1-3$ & 3 & 6 & 9 & 12 & 18 & 24 & 30 & 36 & 42 & 48 & 54 & 60 \\
\hline Clinic visit with inguinal node palpation and DRE & $\mathrm{x}$ & $\mathrm{x}$ & $\mathrm{x}$ & $\mathrm{X}$ & $\mathrm{x}$ & $\mathrm{X}$ & $\mathrm{x}$ & $\mathrm{X}$ & $\mathrm{x}$ & $\mathrm{X}$ & $\mathrm{X}$ & $\mathrm{x}$ & $\mathrm{X}$ \\
\hline Imaging & & PET/CT & $P E T / C T$ & & CT CAP & & CT CAP & & CT CAP & & & & \\
\hline Anoscopy & & $x$ & $\mathrm{x}$ & $x$ & $\mathrm{x}$ & $x$ & $\mathrm{x}$ & $x$ & $\mathrm{x}$ & & & & \\
\hline Gynecology evaluation for women & $x$ & Follow & up inten & is $d t$ & mined & findi & gs at bas & ne & uation ar & bas & net & & \\
\hline HIV viral load (if applicable) & & & Every thi & ee $m c$ & nths or ev & $y$ six & nonths foll & wing & tabilization & [140] & & & \\
\hline
\end{tabular}

Bold: practices according to National Comprehensive Cancer Network Guidelines (Version 2.2017) [139]

Italics: additional survivorship care delivered at our institution

DRE digital rectal exam, PET positron emission tomography scan, CT computerized tomography, CAP computed tomography abdomen and pelvis 
Our approaches to a range of chronic toxicities, sexual health, HIV management in affected patients, psychosocial wellbeing, and surveillance for disease recurrence are reviewed here. This review provides a rigorous and comprehensive summary of the evidence that informs our multi-disciplinary practice, accompanied by expert opinion. In the absence of prospective studies for this rare disease, we believe this review will serve as a resource for oncology care providers, PCP's, and subspecialists who encounter ASCC survivors in clinical practice. While we acknowledge that every setting may not have the comprehensive services available that has been developed for these patients at our institution, we provide references to link providers to knowledge and resources to facilitate appropriate referrals. Moreover, the emotional and social issues experienced by ASCC survivors may be ameliorated by provider awareness and ability to normalize the experiences of this unique patient group.

Our ongoing research is directed at evaluating the impact of this multi-disciplinary approach in a cohort of ASCC survivors. Future clinical trials and observational studies should collect patient reported outcome measures in addition to acute and chronic toxicities. Recent development of a new, validated quality of life questionnaire specific to anal cancer (EORTC QLQANL27) may facilitate future capture of sub-clinical late effects that cause suffering and functional impairment [148]. In addition, future research should include prospective studies that aim to identify effective medical and behavioral interventions that improve the quality of life for patients following treatment for ASCC.

\section{Acknowledgments}

Not applicable.

\section{Authors' contributions}

KVL and MA conceived the article aims and scope. MBS and KVL drafted sections, integrated author contributions, added additional supporting evidence, and addressed revisions. Section leaders were as follows: MA -Management of Chronic Toxicities; TR -Sexual Dysfunction in Female Survivors; BD - Pelvic Floor Dysfunction; JS -Sexual Dysfunction in Male Survivors; CB -HIV Management; ALevin -Psychosocial Wellbeing; ALaffanSurveillance Practices and Survivorship Care Delivery. JMB and TAH provided clinical images. All authors reviewed the manuscript and approved the submitted version.

\section{Funding}

This work was supported by the Mt. Zion Health Fund and the Helen Diller Family Comprehensive Cancer Center at UCSF. Dr. Van Blarigan is supported by National Cancer Institute Grant K07CA197077. The funding agencies were not involved in the design of the study, data collection, analysis, and interpretation, or in preparation of the manuscript. The content of the manuscript does not reflect the views of the funding agencies. Publication made possible in part by support from the UCSF Open Access Publishing Fund.

Availability of data and materials

Works cited are publicly available.
Ethics approval and consent to participate

This article does not contain any studies with human participants or animals performed by any of the authors.

\section{Consent for publication}

Not applicable.

\section{Competing interests}

The authors declare that they have no competing interests.

\section{Author details}

${ }^{1}$ School of Medicine, University of California, San Francisco, USA. ${ }^{2}$ Helen Diller Family Comprehensive Cancer Center, University of California, San Francisco, USA. ${ }^{3}$ Department of Medicine, Division of Infectious Diseases, University of California, San Francisco, USA. ${ }^{4}$ Department of Physical Therapy, University of California, San Francisco, USA. ${ }^{5}$ Department of Psycho-Oncology, University of California, San Francisco, USA. ${ }^{6}$ Department of Obstetrics, Gynecology and Reproductive Sciences, University of California, San Francisco, USA.

${ }^{7}$ Department of Urology, University of California, San Francisco, USA. ${ }^{8}$ Department of Epidemiology and Biostatistics, University of California, San Francisco, USA. ${ }^{9}$ Department of Radiology and Biomedical Imaging, University of California, San Francisco, USA. ${ }^{10}$ Department of Medicine, Division of Hematology/Oncology, University of California, San Francisco, USA. ${ }^{11}$ Department of Radiation Oncology, University of California, San Francisco, USA.

Received: 13 May 2019 Accepted: 19 August 2019

Published online: 11 September 2019

\section{References}

1. National Cancer Institute. Cancer stat facts: Anal cancer. Surveillance, Epidemiology, and End Results Program Web site. https://seer.cancer.gov/ statfacts/html/anus.html. Updated 2017. Accessed 27 Feb 2018.

2. Frisch M, Glimelius B. van den Brule, A J, et al. Sexually transmitted infection as a cause of anal cancer. N Engl J Med. 1997;337(19):1350-8. https://doi. org/10.1056/NEJM199711063371904 Accessed 30 Mar 2018.

3. Hoots BE, Palefsky JM, Pimenta JM, Smith JS. Human papillomavirus type distribution in anal cancer and anal intraepithelial lesions. Int J Cancer. 2009; 124(10):2375-83. https://doi.org/10.1002/ijc.24215 Accessed 30 Mar 2018.

4. Ouhoummane $N$, Steben M, Coutlée F, et al. Squamous anal cancer: Patient characteristics and HPV type distribution. Cancer Epidemiol. 2013;37(6):80712. https://doi.org/10.1016/j.canep.2013.09.015 Accessed 30 Mar 2018.

5. Medford RJ, Salit IE. Anal cancer and intraepithelial neoplasia: Epidemiology, screening and prevention of a sexually transmitted disease. CMAJ. 2015 187(2):111-5. https://doi.org/10.1503/cmaj.140476 Accessed 30 Mar 2018.

6. Engels EA, Pfeiffer RM, Fraumeni JF, et al. Spectrum of cancer risk among US solid organ transplant recipients. JAMA. 2011;306(17):1891-901. https://doi. org/10.1001/jama.2011.1592.

7. Moscicki A, Darragh TM, Berry-Lawhorn JM, et al. Screening for anal cancer in women. J Low Genit Tract Dis. 2015;19(3 Suppl 1):27. https://doi.org/10.1 097/LGT.0000000000000117 Accessed 29 Nov 2018.

8. Shiels MS, Pfeiffer RM, Chaturvedi AK, Kreimer AR, Engels EA. Impact of the HIV epidemic on the incidence rates of anal cancer in the united states. J Natl Cancer Inst. 2012;104(20):1591-8. https://doi.org/10.1093/jnci/djs371 Accessed 29 Nov 2018

9. Islami F, Ferlay J, Lortet-Tieulent J, Bray F, Jemal A. International trends in anal cancer incidence rates. Int J Epidemiol. 2017;46(3):924-38. https://doi. org/10.1093/ije/dyw276 Accessed 29 Nov 2018.

10. James RD, Glynne-Jones R, Meadows HM, et al. Mitomycin or cisplatin chemoradiation with or without maintenance chemotherapy for treatment of squamous-cell carcinoma of the anus (ACT II): A randomised, phase 3 , open-label, 2X2 factorial trial. Lancet Oncol. 2013;14(6):516-24. https://doi. org/10.1016/S1470-2045(13)70086-X http://www.thelancet.com/journals/ lanonc/article/PIIS1470-2045(13)70086-X/abstract.

11. Ajani JA, Winter KA, Gunderson $L L$, et al. Fluorouracil, mitomycin, and radiotherapy vs fluorouracil, cisplatin, and radiotherapy for carcinoma of the anal canal: A randomized controlled trial. JAMA. 2008;299(16):1914-21. https://doi.org/10.1001/jama.299.16.1914 Accessed 30 Mar 2018.

12. Gunderson LL, Winter KA, Ajani JA, et al. Long-term update of US Gl intergroup RTOG 98-11 phase III trial for anal carcinoma: Survival, relapse, and colostomy failure with concurrent chemoradiation involving 
fluorouracil/mitomycin versus fluorouracil/cisplatin. J Clin Oncol. 2012;30(35): 4344-51. https://doi.org/10.1200/JCO.2012.43.8085 Accessed 30 Mar 2018.

13. Fredman E, Abdel-Wahab M, Kumar A. Influence of radiation treatment technique on outcome and toxicity in anal cancer. J Radiat Oncol. 2017;6(4): 413-21. https://doi.org/10.1007/s13566-017-0326-3 https://www.ncbi.nlm. nih.gov/pubmed/29213359.

14. Fish R, Sanders C, Williamson PR, Renehan AG. Core outcome research measures in anal cancer (CORMAC): Protocol for systematic review, qualitative interviews and delphi survey to develop a core outcome set in anal cancer. BMJ Open. 2017;7(11):e018726. https://doi.org/10.1136/ bmjopen-2017-018726.

15. Fish $R$, Sanders $C$, Adams $R$, et al. A core outcome set for clinical trials of chemoradiotherapy interventions for anal cancer (CORMAC): A patient and health-care professional consensus. Lancet Gastroenterol Hepatol. 2018; 3(12):865-73. https://doi.org/10.1016/S2468-1253(18)30264-4 https://www. sciencedirect.com/science/article/pii/S2468125318302644.

16. Frick MA, Vachani CC, Hampshire MK, et al. Survivorship after lower gastrointestinal cancer: Patient-reported outcomes and planning for care. Cancer. 2017;123(10):1860-8. https://doi.org/10.1002/cncr.30527 Accessed 28 Feb 2018

17. Ka'opua LSI, Cassel K, Shiramizu B, et al. Addressing risk and reluctance at the nexus of HIV and anal cancer screening. Health Promot Pract. 2016; 17(1):21-30. https://doi.org/10.1177/1524839915615611 https://journals. sagepub.com/doi/full/10.1177/1524839915615611.

18. Simard EP, Watson M, Saraiya M, Clarke CA, Palefsky JM, Jemal A. Trends in the occurrence of high-grade anal intraepithelial neoplasia in san francisco: 2000-2009. Cancer. 2013;119(19):3539-45. https://doi.org/10.1002/cncr.28252 http://onlinelibrary.wiley.com/doi/10.1002/cncr.28252/abstract.

19. Amirian ES, Fickey PA Jr, Scheurer ME, Chiao EY. Anal cancer incidence and survival: Comparing the greater san-francisco bay area to other SEER cancer registries. PLoS One. 2013;8(3):e58919. https://doi.org/10.1371/journal.pone. 0058919 http://www.ncbi.nlm.nih.gov/pubmed/23484057.

20. Mitchell MP, Abboud M, Eng C, et al. Intensity-modulated radiation therapy with concurrent chemotherapy for anal cancer: Outcomes and toxicity. Am J Clin Oncol. 2014;37(5):461-6. https://doi.org/10.1097/COC.0b013e31827e52 a3 Accessed 27 June 2018

21. Mitra D, Hong TS, Horick N, et al. Long-term outcomes and toxicities of a large cohort of anal cancer patients treated with dose-painted IMRT per RTOG 0529. Adv Radiat Oncol. 2017;2(2):110-7. https://doi.org/10.1016/j. adro.2017.01.009 http://www.sciencedirect.com/science/article/pii/S24521 09417300143. Accessed 29 July 2018.

22. National Cancer Institute. Common terminology criteria for adverse events v4.0 (CTCAE). https://evs.nci.nih.gov/ftp1/CTCAE/CTCAE_4.03/Archive/ CTCAE_4.0_2009-05-29_QuickReference_8.5x11.pdf. Updated 2009. Accessed July 29, 2018 .

23. Tomaszewski JM, Link E, Leong T, et al. Twenty-five-year experience with radical chemoradiation for anal cancer. Int J Radiat Oncol Biol Phys. 2012;83(2): 552-8. https:/doi.org/10.1016/j.jirobp.2011.07.007 Accessed 31 July 2018.

24. Cox JD, Stetz J, Pajak TF. Toxicity criteria of the radiation therapy oncology group (RTOG) and the european organization for research and treatment of cancer (EORTC). Int J Radiat Oncol Biol Phys. 1995;31(5):1341-6. https://doi. org/10.1016/0360-3016(95)00060-C Accessed 29 July 2018.

25. Andreyev J. Gastrointestinal symptoms after pelvic radiotherapy: A new understanding to improve management of symptomatic patients. Lancet Oncol. 2007;8(11):1007-17. https://doi.org/10.1016/S1470-2045(07)70341-8 Accessed 22 May 2018

26. Olopade FA, Norman A, Blake P, et al. A modified inflammatory bowel disease questionnaire and the vaizey incontinence questionnaire are simple ways to identify patients with significant gastrointestinal symptoms after pelvic radiotherapy. Br J Cancer. 2005;92(9):1663-70. https://doi.org/10.1038/ sj.bjc.6602552 Accessed 29 July 2018.

27. Gami B, Harrington K, Blake P, et al. How patients manage gastrointestinal symptoms after pelvic radiotherapy. Aliment Pharmacol Ther. 2003;18(10): 987-94. https://doi.org/10.1046/j.1365-2036.2003.01760.x http://www. ingentaconnect.com/content/bsc/apt/2003/00000018/00000010/art00005.

28. Knowles $G$, Haigh R, McLean C, Phillips $H$. Late effects and quality of life after chemo-radiation for the treatment of anal cancer. Eur J Oncol Nurs. 2015;19(5): 479-85. https://doi.org/10.1016/.jejon.2015.02.007 Accessed 27 Mar 2018.

29. Das $\mathrm{P}$, Cantor $\mathrm{SB}$, Parker $\mathrm{CL}$, et al. Long-term quality of life after radiotherapy for the treatment of anal cancer. Cancer. 2010;116(4):822-9. https://doi.org/1 0.1002/cncr.24906 Accessed 27 Mar 2018.
30. Welzel G, Hägele V, Wenz F, Mai SK. Quality of life outcomes in patients with anal cancer after combined radiochemotherapy. Strahlenther Onkol. 2011;187(3):175-82. https://doi.org/10.1007/s00066-010-2175-5 Accessed 22 May 2018.

31. Allal AS, Sprangers MA, Laurencet F, Reymond MA, Kurtz JM. Assessment of long-term quality of life in patients with anal carcinomas treated by radiotherapy with or without chemotherapy. Br J Cancer. 1999;80(10):1588-94. https://doi.org/10.1038/sj.bjc.6690567 Accessed 22 May 2018.

32. Fakhrian K, Sauer T, Dinkel A, et al. Chronic adverse events and quality of life after radiochemotherapy in anal cancer patients. A single institution experience and review of the literature. Strahlenther Onkol. 2013;189(6):486-94 https://doi.org/10.1007/s00066-013-0314-5 Accessed 22 May 2018.

33. Bentzen $A G$, Balteskard L, Wanderås EH, et al. Impaired health-related quality of life after chemoradiotherapy for anal cancer: Late effects in a national cohort of 128 survivors. Acta Oncol. 2013;52(4):736-44. https://doi.org/10.31 09/0284186X.2013.770599 Accessed 27 Mar 2018.

34. Jephcott CR, Paltiel C, Hay J. Quality of life after non-surgical treatment of anal carcinoma: A case control study of long-term survivors. Clin Oncol (R Coll Radiol). 2004;16(8):530-5 Accessed 27 Mar 2018.

35. Provencher S, Oehler C, Lavertu S, Jolicoeur M, Fortin B, Donath D. Quality of life and tumor control after short split-course chemoradiation for anal canal carcinoma. Radiat Oncol. 2010;5:41. https://doi.org/10.1186/1748-71 7X-5-41 Accessed 27 Mar 2018.

36. Andreyev HJN, Benton BE, Lalji A, et al. Algorithm-based management of patients with gastrointestinal symptoms in patients after pelvic radiation treatment (ORBIT): A randomised controlled trial. Lancet. 2013:382(9910):2084-92. https://doi.org/10.1016/S0140-6736(13)61648-7 Accessed 29 July 2018.

37. De Francesco I, Thomas K, Wedlake L, Tait D. Intensity-modulated radiotherapy and anal cancer: Clinical outcome and late toxicity assessment. Clin Oncol. 2016;28(9):604-10. https://doi.org/10.1016/..clon.2016.04.039 http://www.sciencedirect.com/science/article/pii/S0936655516300668. Accessed 22 May 2018.

38. Yeoh EK, Horowitz M, Russo A, Muecke T, Robb T, Chatterton BE. Gastrointestinal function in chronic radiation enteritis--effects of loperamide-N-oxide. Gut. 1993;34(4):476-82 Accessed 21 Nov 2018.

39. Sekhon S. Chronic radiation enteritis: Women's food tolerances after radiation treatment for gynecologic cancer. J Am Diet Assoc. 2000;100(8):941-3. https:/ doi.org/10.1016/S0002-8223(00)00270-4 Accessed 21 Nov 2018.

40. Zimmerer T, Böcker U, Wenz F, Singer MV. Medical prevention and treatment of acute and chronic radiation induced enteritis--is there any proven therapy? a short review. Z Gastroenterol. 2008;46(5):441-8. https:// doi.org/10.1055/s-2008-1027150 Accessed 21 Nov 2018.

41. Galland RB, Spencer J. Surgical management of radiation enteritis. Surgery. 1986;99(2):133-9 Accessed 22 May 2018.

42. Girvent M, Carlson GL, Anderson I, Shaffer J, Irving M, Scott NA. Intestinal failure after surgery for complicated radiation enteritis. Ann R Coll Surg Engl. 2000;82(3):198-201 Accessed 22 May 2018.

43. Kuroki F, lida M, Matsui T, Matsumoto T, Fujishima M, Yao T. Intraoperative endoscopy for small intestinal damage in radiation enteritis. Gastrointest Endosc. 1992;38(2):196-7 Accessed 22 May 2018.

44. Schultheiss TE, Lee WR, Hunt MA, Hanlon AL, Peter RS, Hanks GE. Late Gl and GU complications in the treatment of prostate cancer. Int J Radiat Oncol Biol Phys. 1997;37(1):3-11 Accessed 22 May 2018.

45. Gilinsky NH, Burns DG, Barbezat GO, Levin W, Myers HS, Marks IN. The natural history of radiation-induced proctosigmoiditis: An analysis of 88 patients. Q J Med. 1983;52(205):40-53 Accessed 22 May 2018.

46. Chun M, Kang S, Kil H, Oh Y, Sohn J, Ryu H. Rectal bleeding and its management after irradiation for uterine cervical cancer. Int J Radiat Oncol Biol Phys. 2004;58(1):98-105 Accessed 22 May 2018.

47. Sasai T, Hiraishi H, Suzuki Y, Masuyama H, Ishida M, Terano A. Treatment of chronic post-radiation proctitis with oral administration of sucralfate. Am J Gastroenterol. 1998;93(9):1593-5. https://doi.org/10.1111/j.1572-0241.1998. 00493.x Accessed 22 May 2018.

48. Stockdale $A D$, Biswas $A$. Long-term control of radiation proctitis following treatment with sucralfate enemas. Br J Surg. 1997;84(3):379 Accessed 22 May 2018.

49. Gul YA, Prasannan S, Jabar FM, Shaker ARH, Moissinac K. Pharmacotherapy for chronic hemorrhagic radiation proctitis. World J Surg. 2002;26(12):1499502. https://doi.org/10.1007/s00268-002-6529-8 Accessed 22 May 2018.

50. Kochhar R, Patel F, Dhar A, et al. Radiation-induced proctosigmoiditis. prospective, randomized, double-blind controlled trial of oral sulfasalazine 
plus rectal steroids versus rectal sucralfate. Dig Dis Sci. 1991;36(1):103-7 Accessed 22 May 2018

51. Hanson B, MacDonald R, Shaukat A. Endoscopic and medical therapy for chronic radiation proctopathy: A systematic review. Dis Colon Rectum. 2012; 55(10):1081-95. https://doi.org/10.1097/DCR.0b013e3182587aef Accessed 22 May 2018.

52. Lenz L, Rohr R, Nakao F, Libera E, Ferrari A. Chronic radiation proctopathy: A practical review of endoscopic treatment. World J Gastrointest Surg. 2016; 8(2):151-60. https://doi.org/10.4240/wjgs.v8.i2.151 Accessed 23 May 2018.

53. Silva RA, Correia AJ, Dias LM, Viana HL, Viana RL. Argon plasma coagulation therapy for hemorrhagic radiation proctosigmoiditis. Gastrointest Endosc. 1999;50(2):221-4 Accessed 22 May 2018.

54. Tjandra JJ, Sengupta S. Argon plasma coagulation is an effective treatment for refractory hemorrhagic radiation proctitis. Dis Colon Rectum. 2001;44(12): 175-1765 discussion 1771. Accessed 22 May 2018.

55. Taïeb S, Rolachon A, Cenni JC, et al. Effective use of argon plasma coagulation in the treatment of severe radiation proctitis. Dis Colon Rectum. 2001;44(12):1766-71 Accessed 22 May 2018.

56. McCarty TR, Rustagi T. New indications for endoscopic radiofrequency ablation. Clin Gastroenterol Hepatol. 2018. https://doi.org/10.1016/j.cgh.201 7.10.023 Accessed 23 May 2018.

57. Luna-Pérez P, Rodríguez-Ramírez SE. Formalin instillation for refractory radiation-induced hemorrhagic proctitis. J Surg Oncol. 2002;80(1):41-4. https://doi.org/10.1002/jso.10095 Accessed 23 May 2018.

58. Counter SF, Froese DP, Hart MJ. Prospective evaluation of formalin therapy for radiation proctitis. Am J Surg. 1999;177(5):396-8 Accessed 23 May 2018.

59. Weiner J, Schwartz D, Martinez M, Safdieh J, Aytaman A, Schreiber D. Longterm results on the efficacy of argon plasma coagulation for patients with chronic radiation proctitis after conventionally fractionated, dose-escalated radiation therapy for prostate cancer. Pract Radiat Oncol. 2017;7(1):e3-e42. https://doi.org/10.1016/j.prro.2016.07.009 Accessed 23 May 2018.

60. Ben Soussan E, Mathieu N, Roque I, Antonietti M. Bowel explosion with colonic perforation during argon plasma coagulation for hemorrhagic radiation-induced proctitis. Gastrointest Endosc. 2003;57(3):412-3. https:// doi.org/10.1067/mge.2003.131 Accessed 23 May 2018.

61. Alfadhli AA, Alazmi WM, Ponich T, et al. Efficacy of argon plasma coagulation compared to topical formalin application for chronic radiation proctopathy. Can J Gastroenterol. 2008;22(2):129-32 Accessed 23 May 2018.

62. Bennett MH, Feldmeier J, Hampson NB, Smee R, Milross C. Hyperbaric oxygen therapy for late radiation tissue injury. Cochrane Database Syst Rev. 2016;4. https://doi.org/10.1002/14651858.CD005005.pub4.

63. Clarke RE, Tenorio LMC, Hussey JR, et al. Hyperbaric oxygen treatment of chronic refractory radiation proctitis: A randomized and controlled doubleblind crossover trial with long-term follow-up. Int J Radiat Oncol Biol Phys. 2008;72(1):134-43. https://doi.org/10.1016/j.jirobp.2007.12.048 Accessed 22 Sept 2018.

64. Rezaie A, Pimentel M, Rao S. How to test and treat small intestinal bacterial overgrowth: An evidence-based approach. Curr Gastroenterol Rep. 2016; 18(2):1-11. https://doi.org/10.1007/s1 1894-015-0482-9 https://www.ncbi.nlm. nih.gov/pubmed/26780631.

65. Andreyev HJN, Davidson SE, Gillespie C, Allum WH, Swarbrick E. Practice guidance on the management of acute and chronic gastrointestinal problems arising as a result of treatment for cancer. Gut. 2012;61(2):179-92. https://doi.org/10.1136/gutjnl-2011-300563 Accessed 29 July 2018.

66. Arbea L, Ramos LI, Martínez-Monge R, Moreno M, Aristu J. Intensitymodulated radiation therapy (IMRT) vs. 3D conformal radiotherapy (3DCRT) in locally advanced rectal cancer (LARC): Dosimetric comparison and clinical implications. Radiat Oncol. 2010;5:17. https://doi.org/10.1186/1748-717X-5-17 Accessed 26 June 2018.

67. Nicholas $\mathrm{S}$, Chen $\mathrm{L}$, Choflet $\mathrm{A}$, et al. Pelvic radiation and normal tissue toxicity. Semin Radiat Oncol. 2017;27(4):358-69. https://doi.org/10.1016/j. semradonc.2017.04.010 Accessed 26 June 2018.

68. Viswanathan AN, Lee LJ, Eswara JR, et al. Complications of pelvic radiation in patients treated for gynecologic malignancies. Cancer. 2014;120(24):387083. https://doi.org/10.1002/cncr.28849 Accessed 26 June 2018.

69. Michalecki L, Gabryś D, Kulik R, Wydmański J, Trela K. Radiotherapy induced hip joint avascular necrosis-two cases report. Rep Pract Oncol Radiother. 2011;16(5):198-201. https://doi.org/10.1016/j.rpor.2011.04.004 Accessed 26 June 2018.

70. Micha JP, Goldstein BH, Rettenmaier MA, Caillouette JT, Fee MJ, Brown JV. Pelvic radiation necrosis and osteomyelitis following chemoradiation for advanced stage vulvar and cervical carcinoma. Gynecol Oncol. 2006;101(2): 349-52. https://doi.org/10.1016/.ygyno.2005.12.007 Accessed 26 June 2018.

71. Papadopoulou I, Stewart V, Barwick TD, et al. Post-radiation therapy imaging appearances in cervical carcinoma. Radiographics. 2016;36(2):538-53. https://doi.org/10.1148/rg.2016150117 Accessed 26 June 2018.

72. Bazire $L, X u H$, Foy J, et al. Pelvic insufficiency fracture (PIF) incidence in patients treated with intensity-modulated radiation therapy (IMRT) for gynaecological or anal cancer: Single-institution experience and review of the literature. Br J Radiol. 2017;90(1073):20160885. https://doi.org/10.1259/ bjr.20160885 Accessed 15 May 2018.

73. Shih KK, Folkert MR, Kollmeier MA, et al. Pelvic insufficiency fractures in patients with cervical and endometrial cancer treated with postoperative pelvic radiation. Gynecol Oncol. 2013;128(3):540-3. https://doi.org/10.1016/j. ygyno.2012.12.021 Accessed 26 June 2018.

74. Uezono H, Tsujino K, Moriki K, et al. Pelvic insufficiency fracture after definitive radiotherapy for uterine cervical cancer: Retrospective analysis of risk factors. J Radiat Res. 2013;54(6):1102-9. https://doi.org/10.1093/jrr/rrt055 Accessed 28 July 2018.

75. Kim HJ, Boland PJ, Meredith DS, et al. Fractures of the sacrum after chemoradiation for rectal carcinoma: Incidence, risk factors, and radiographic evaluation. Int J Radiat Oncol Biol Phys. 2012;84(3):694-9. https://doi.org/10.1016/j.jijobp.2012.01.021 Accessed 15 May 2018.

76. Tokumaru S, Toita T, Oguchi M, et al. Insufficiency fractures after pelvic radiation therapy for uterine cervical cancer: An analysis of subjects in a prospective multi-institutional trial, and cooperative study of the japan radiation oncology group (JAROG) and japanese radiation oncology study group (JROSG). Int J Radiat Oncol Biol Phys. 2012;84(2):195. https://doi.org/1 0.1016/j.jijobp.2012.03.042 Accessed 28 July 2018.

77. Schmeler KM, Jhingran A, lyer RB, et al. Pelvic fractures after radiotherapy for cervical cancer: Implications for survivors. Cancer. 2010;116(3):625-30. https://doi.org/10.1002/cncr.24811 Accessed 25 June 2018.

78. Herman MP, Kopetz S, Bhosale PR, et al. Sacral insufficiency fractures after preoperative chemoradiation for rectal cancer: Incidence, risk factors, and clinical course. Int J Radiat Oncol Biol Phys. 2009;74(3):818-23. https://doi. org/10.1016/j.jijobp.2008.08.054 http://www.sciencedirect.com/science/ article/pii/S0360301608035086. Accessed 17 May 2018.

79. Oh D, Huh SJ, Nam H, et al. Pelvic insufficiency fracture after pelvic radiotherapy for cervical cancer: Analysis of risk factors. Int J Radiat Oncol Biol Phys. 2008;70(4):1183-8. https://doi.org/10.1016/j.jjrobp.2007.08.005 Accessed 26 June 2018.

80. Kwon JW, Huh SJ, Yoon YC, et al. Pelvic bone complications after radiation therapy of uterine cervical cancer: Evaluation with MRI. AJR Am J Roentgenol. 2008;191(4):987-94. https://doi.org/10.2214/AJR.07.3634 Accessed 28 July 2018.

81. Ikushima H, Osaki K, Furutani S, et al. Pelvic bone complications following radiation therapy of gynecologic malignancies: Clinical evaluation of radiation-induced pelvic insufficiency fractures. Gynecol Oncol. 2006;103(3): 1100-4. https://doi.org/10.1016/j.ygyno.2006.06.038 Accessed 28 July 2018.

82. Baxter NN, Habermann EB, Tepper JE, Durham SB, Virnig BA. Risk of pelvic fractures in older women following pelvic irradiation. JAMA. 2005;294(20): 2587-93. https://doi.org/10.1001/jama.294.20.2587 Accessed 25 June 2018.

83. Ogino I, Okamoto N, Ono Y, Kitamura T, Nakayama H. Pelvic insufficiency fractures in postmenopausal woman with advanced cervical cancer treated by radiotherapy. Radiother Oncol. 2003;68(1):61-7. https://doi.org/10.1016/ S0167-8140(03)00128-2 http://www.sciencedirect.com/science/article/pii/ S0167814003001282. Accessed 17 May 2018.

84. Tai P, Hammond A, Dyk JV, et al. Pelvic fractures following irradiation of endometrial and vaginal cancers-a case series and review of literature. Radiother Oncol. 2000;56(1):23-8 Accessed 28 July 2018.

85. Grant PM, Kitch D, McComsey GA, et al. Long-term bone mineral density changes in antiretroviral-treated HIV-infected individuals. J Infect Dis. 2016; 214(4):607-11. https://doi.org/10.1093/infdis/jiw204 https://www.ncbi.nlm. nih.gov/pubmed/27330053.

86. Peh WCG, Khong PL, Sham JST, Ho WY, Yeung HWD. Sacral and pubic insufficiency fractures after irradiation of gynaecological malignancies. Clin Oncol. 1995;7(2):117-22. https://doi.org/10.1016/S0936-6555(05)80814-3 http://www.sciencedirect.com/science/article/pii/S0936655505808143. Accessed 17 May 2018.

87. Moreno A, Clemente J, Crespo C, et al. Pelvic insufficiency fractures in patients with pelvic irradiation. Int J Radiat Oncol Biol Phys. 1999;44(1):61-6. https://doi.org/10.1016/S0360-3016(98)00534-3 http://www.sciencedirect. com/science/article/pii/S0360301698005343. Accessed 17 May 2018. 
88. Denlinger CS, Sanft T. Clinical practice guidelines in oncology (NCCN guidelines) survivorship (version 3.2017): National Comprehensive Cancer Network; 2018.

89. Bernard S, Ouellet M, Moffet H, Roy J, Dumoulin C. Effects of radiation therapy on the structure and function of the pelvic floor muscles of patients with cancer in the pelvic area: A systematic review. J Cancer Surviv. 2016;10(2):351-62. https://doi.org/10.1007/s11764-015-0481-8 Accessed 12 July 2018.

90. Yang EJ, Lim J, Rah UW, Kim YB. Effect of a pelvic floor muscle training program on gynecologic cancer survivors with pelvic floor dysfunction: A randomized controlled trial. Gynecol Oncol. 2012;125(3):705-11. Accessed 12 July 2018. https://doi.org/10.1016/j.ygyno.2012.03.045.

91. Huffman LB, Hartenbach EM, Carter J, Rash JK, Kushner DM. Maintaining sexual health throughout gynecologic cancer survivorship: A comprehensive review and clinical guide. Gynecol Oncol. 2016;140(2):35968. https://doi.org/10.1016/j.ygyno.2015.11.010 Accessed 12 July 2018.

92. Jensen PT, Froeding LP. Pelvic radiotherapy and sexual function in women Transl Androl Urol. 2015;4(2):186-205. https://doi.org/10.3978/j.issn.2223-46 83.2015.04.06 Accessed 9 Apr 2018.

93. DuHamel K, Schuler T, Nelson C, et al. The sexual health of female rectal and anal cancer survivors: Results of a pilot randomized psycho-educational intervention trial. J Cancer Surviv. 2016;10(3):553-63. https://doi.org/10.1007/ s11764-015-0501-8 Accessed 9 Apr 2018.

94. Ho VP, Lee Y, Stein SL, Temple LKF. Sexual function after treatment for rectal cancer: A review. Dis Colon Rectum. 2011;54(1):113-25. https://doi. org/10.1007/DCR.0b013e3181fb7b82 Accessed 9 Apr 2018.

95. Panjari M, Bell RJ, Burney S, Bell S, McMurrick PJ, Davis SR. Sexual function, incontinence, and wellbeing in women after rectal cancer--a review of the evidence. J Sex Med. 2012;9(11):2749-58. https://doi.org/10.1111/j.1743-61 09.2012.02894.x Accessed 9 Apr 2018

96. Sakurai K, Matsuo S, Enomoto K, Amano S, Shiono M. Menstruation recovery after chemotherapy and luteinizing hormone-releasing hormone agonist plus tamoxifen therapy for premenopausal patients with breast cancer. Surg Today. 2011;41(1):48-53. https://doi.org/10.1007/s00595-009-4226-z Accessed 9 Apr 2018.

97. Maneschi F, Benedetti-Panici P, Scambia G, Salerno MG, D'Agostino G, Mancuso S. Menstrual and hormone patterns in women treated with highdose cisplatin and bleomycin. Gynecol Oncol. 1994;54(3):345-8. https://doi. org/10.1006/gyno.1994.1221 Accessed 9 Apr 2018.

98. Mirabeau-Beale K, Hong TS, Niemierko A, et al. Clinical and treatment factors associated with vaginal stenosis after definitive chemoradiation for anal canal cancer. Pract Radiat Oncol. 2015;5(3):113. Accessed 26 Apr 2018. https://doi.org/10.1016/j.prro.2014.09.003.

99. Miles T, Johnson N. Vaginal dilator therapy for women receiving pelvic radiotherapy. Cochrane Database Syst Rev. 2014;(9):CD007291. https://doi. org/10.1002/14651858.CD007291.pub3 Accessed 9 Apr 2018.

100. Cullen K, Fergus K, Dasgupta T, Fitch M, Doyle C, Adams L. From "sex toy" to intrusive imposition: A qualitative examination of women's experiences with vaginal dilator use following treatment for gynecological cancer. J Sex Med. 2012;9(4):1162-73. https://doi.org/10.1111/j.1743-6109.2011.02639.x Accessed 9 Apr 2018.

101. Morris L, Do V, Chard J, Brand AH. Radiation-induced vaginal stenosis: Current perspectives. Int J Women's Health. 2017;9:273-9. Accessed 9 Apr 2018. https://doi.org/10.2147/IJWH.S106796.

102. Conte B, Del Mastro L. Gonadotropin-releasing hormone analogues for the prevention of chemotherapy-induced premature ovarian failure in breast cancer patients. Minerva Ginecol. 2017;69(4):350-6. https://doi.org/10.23736/ S0026-4784.17.04067-9 Accessed 9 Apr 2018.

103. Moore HCF, Unger JM, Phillips K, et al. Final analysis of the prevention of early menopause study (POEMS)/SWOG intergroup S0230. J Natl Cancer Inst. 2018. https://doi.org/10.1093/jnci/djy185 Accessed 20 Nov 2018.

104. Thor M, Olsson CE, Oh JH, et al. Radiation dose to the penile structures and Patient-Reported sexual dysfunction in Long-Term prostate cancer survivors. J Sex Med. 2015;12(12):2388-97. https://doi.org/10.1111/jsm.13031 https:// www.sciencedirect.com/science/article/pii/S1743609516300042.

105. Levine FJ, Greenfield AJ, Goldstein I. Arteriographically determined occlusive disease within the hypogastric-cavernous bed in impotent patients following blunt perineal and pelvic trauma. J Urol. 1990;144(5):1147-53 Accessed 28 Mar 2018

106. Rosen MP, Greenfield AJ, Walker TG, et al. Cigarette smoking: An independent risk factor for atherosclerosis in the hypogastric-cavernous arterial bed of men with arteriogenic impotence. J Urol. 1991;145(4):759-63 Accessed 28 Mar 2018

107. Miner M, Billups KL. Erectile dysfunction and dyslipidemia: Relevance and role of phosphodiesterase type-5 inhibitors and statins. J Sex Med. 2008;5(5): 1066-78. https://doi.org/10.1111/j.1743-6109.2008.00783.x Accessed 28 Mar 2018.

108. Araujo AB, Durante R, Feldman HA, Goldstein I, McKinlay JB. The relationship between depressive symptoms and male erectile dysfunction: Crosssectional results from the massachusetts male aging study. Psychosom Med. 1998;60(4):458-65 Accessed 28 Mar 2018.

109. Shabsigh R, Klein LT, Seidman S, Kaplan SA, Lehrhoff BJ, Ritter JS. Increased incidence of depressive symptoms in men with erectile dysfunction. Urology. 1998;52(5):848-52 Accessed 28 Mar 2018.

110. Schiff JD, Bar-Chama N, Cesaretti J, Stock R. Early use of a phosphodiesterase inhibitor after brachytherapy restores and preserves erectile function. BJU Int. 2006;98(6):1255-8. https://doi.org/10.1111/ j.1464-410X.2006.06441.x Accessed 28 Mar 2018.

111. Incrocci L, Koper PCM, Hop WCJ, Slob AK. Sildenafil citrate (viagra) and erectile dysfunction following external beam radiotherapy for prostate cancer: A randomized, double-blind, placebo-controlled, cross-over study. Int J Radiat Oncol Biol Phys. 2001;51(5):1190-5. https://doi.org/10.1016/S036 0-3016(01)01767-9 https://www.sciencedirect.com/science/article/pii/S03603 01601017679

112. Incrocci L, Slagter C, Slob AK, Hop WCJ. A randomized, double-blind, placebo-controlled, cross-over study to assess the efficacy of tadalafil (cialis ${ }^{\circledR}$ ) in the treatment of erectile dysfunction following three-dimensional conformal external-beam radiotherapy for prostatic carcinoma. Int J Radiat Oncol Biol Phys. 2006;66(2):439-44. https://doi.org/10.1016/j.ijrobp.2006.04.047 https:// www.sciencedirect.com/science/article/pii/S0360301606009448

113. DeBusk R, Drory Y, Goldstein I, et al. Management of sexual dysfunction in patients with cardiovascular disease: Recommendations of the princeton consensus panel. Am J Cardiol. 2000;86(2):175-81 Accessed 28 Mar 2018.

114. Chaturvedi AK, Madeleine MM, Biggar RJ, Engels EA. Risk of human papillomavirus-associated cancers among persons with AIDS. J Natl Cancer Inst. 2009;101(16):1120-30. https://doi.org/10.1093/jnci/djp205 Accessed 6 Apr 2018.

115. Franceschi S, Lise M, Clifford GM, et al. Changing patterns of cancer incidence in the early- and late-HAART periods: The swiss HIV cohort study. Br J Cancer. 2010;103(3):416-22. https://doi.org/10.1038/sj.bjc.6605756 Accessed 6 Apr 2018.

116. Piketty $C$, Selinger-Leneman H, Bouvier A, et al. Incidence of HIV-related anal cancer remains increased despite long-term combined antiretroviral treatment: Results from the french hospital database on HIV. J Clin Oncol. 2012;30(35): 4360-6. https://doi.org/10.1200/JCO.2012.44.5486 Accessed 6 Apr 2018.

117. Silverberg MJ, Lau B, Justice AC, et al. Risk of anal cancer in HIV-infected and HIV-uninfected individuals in north america. Clin Infect Dis. 2012;54(7): 1026-34. https://doi.org/10.1093/cid/cir1012 Accessed 7 Apr 2018.

118. Bryant AK, Huynh-Le M, Simpson DR, Gupta S, Sharabi AB, Murphy JD. Association of HIV status with outcomes of anal squamous cell carcinoma in the era of highly active antiretroviral therapy. JAMA Oncol. 2018;4(1):120-2. https://doi.org/10.1001/jamaoncol.2017.2844 Accessed 7 Apr 2018.

119. Chiao EY, Giordano TP, Richardson P. El-Serag HB. Human immunodeficiency virus-associated squamous cell cancer of the anus: Epidemiology and outcomes in the highly active antiretroviral therapy era. J Clin Oncol. 2008;26(3):474-9. Accessed 7 Apr 2018. https://doi.org/10.1200/ JCO.2007.14.2810.

120. Oehler-Jänne C, Huguet F, Provencher S, et al. HIV-specific differences in outcome of squamous cell carcinoma of the anal canal: A multicentric cohort study of HIV-positive patients receiving highly active antiretroviral therapy. J Clin Oncol. 2008;26(15):2550-7. https://doi.org/10.1200/JCO.2 007.15.2348 Accessed 7 Apr 2018.

121. Aberg JA, Gallant JE, Ghanem KG, Emmanuel P, Zingman BS, Horberg MA. Primary care guidelines for the management of persons infected with HIV 2013 update by the HIV medicine association of the infectious diseases society of america. Clin Infect Dis. 2014;58(1):1-10. https://doi.org/10.1093/ cid/cit757 Accessed 9 Apr 2018.

122. Network N. Cancer in people living with HIV (version 1.2018). https://www. nccn.org/professionals/physician_gls/default.aspx. Updated 2018. Accessed 29 Mar 2018.

123. Torres HA, Mulanovich V. Management of HIV infection in patients with cancer receiving chemotherapy. Clin Infect Dis. 2014;59(1):106-14. https:// doi.org/10.1093/cid/ciu174 Accessed 9 Apr 2018. 
124. Panel on Opportunistic Infections in HIV-Infected Adults and Adolescents. Guidelines for the prevention and treatment of opportunistic infections in HIV-infected adults and adolescents: Recommendations from the centers for disease control and prevention, the national institutes of health, and the HIV medicine association of the infectious diseases society of america. 2018.

125. Holland JC, Barbara Andersen P, Breitbart WS, Dabrowski M, et al. The NCCN distress management clinical practice guidelines in oncology. J Natl Compr Cancer Netw. 2010;8(4):448-85.

126. Custers JAE, Gielissen MFM, Janssen SHV, de Wilt JHW, Prins JB. Fear of cancer recurrence in colorectal cancer survivors. Support Care Cancer. 2016; 24(2):555-62. https://doi.org/10.1007/s00520-015-2808-4 Accessed 9 Apr 2018.

127. Simonelli LE, Siegel SD, Duffy NM. Fear of cancer recurrence: A theoretical review and its relevance for clinical presentation and management. Psychooncology. 2017;26(10):1444-54. https://doi.org/10.1002/pon.4168 Accessed 9 Apr 2018.

128. European Foundation for Psychologists and Analysts. European psychology directory. EFPA Web site. http://www.efpa.be/. Accessed 20 July 2019.

129. Psychology today: Find a therapist. Psychology Today Web site. https://www. psychologytoday.com/blog-posts. Updated 2018. Accessed 23 Sept 2018.

130. The American Cancer Society medical and editorial content team. Nutrition and physical activity during and after cancer treatment: Answers to common questions. American Cancer Society Web site. https://www.cancer. org/treatment/survivorship-during-and-after-treatment/staying-active/ nutrition/nutrition-and-physical-activity-during-and-after-cancer-treatment. html. Updated 2013. Accessed 21 Nov 2018.

131. Find support / patient support / connect with a peer. The HPV and Anal Cancer Foundation Web site. https://www.analcancerfoundation.org/findsupport/patient-support/connect-with-a-peer/. Accessed 10 Apr 2018.

132. Quinn GP, Sanchez JA, Sutton SK, et al. Cancer and lesbian, gay, bisexual, transgender/transsexual, and queer/questioning (LGBTQ) populations. CA Cancer J Clin. 2015;65(5):384-400. https://doi.org/10.3322/caac.21288 Accessed 9 Apr 2018.

133. For patients -find provider. Gay and Lesbian Medical Association Web site. http://www.glma.org/index.cfm?fuseaction=Page.viewPage\&pageld=93 9\&grandparent $\mid \mathrm{D}=534 \&$ parent $\mid \mathrm{D}=938 \&$ nodelD=1. Accessed 23 Sept 2018.

134. Smalley B, Warren J, Barefoot N. LBGT health: Meeting the needs of gender and sexual minorities: Springer Publishing Company; 2017.

135. Butler M, McCreedy E, Schwer N, et al. Lesbian, gay, bisexual, and transgender populations: Agency for Healthcare Research and Quality (US); 2016. https://www.ncbi.nlm.nih.gov/books/NBK361118/. Accessed 9 Apr 2018

136. Commission on Cancer. Cancer program standards: Ensuring patientcentered care; 2016. p. 58-9.

137. Schmitz KH, Courneya KS, Matthews C, et al. American college of sports medicine roundtable on exercise guidelines for cancer survivors. Med Sci Sports Exerc. 2010;42(7):1409-26. https://doi.org/10.1249/MSS.0b013e3181 e0c112 Accessed 15 Dec 2018.

138. Staying healthy after treatment. American Institute for Cancer Research Web site. http://www.aicr.org/patients-survivors/staying-healthy-after-treatment/. Updated 2018. Accessed 10 Apr 2018.

139. Benson A, Venook A. Clinical practice guidelines in oncology (NCCN guidelines) anal carcinoma (version 2.2017): National Comprehensive Cancer Network; 2017.

140. Panel on Antiretroviral Guidelines for Adults and Adolescents. Guidelines for the use of antiretroviral agents in adults and adolescents living with HIV. AIDS Info. 2018

141. De Felice F, Martinetti MT, Orelli S, Bulzonetti N, Musio D, Tombolini V. Definitive chemoradiotherapy for anal carcinoma: Long-term results based on consistent time-to-event endpoints. Oncology. 2018;94(1):25-30. https:// doi.org/10.1159/000479971 Accessed 10 Apr 2018.

142. Goldman KE, White EC, Rao AR, Kaptein JS, Lien WW. Posttreatment FDGPET-CT response is predictive of tumor progression and survival in anal carcinoma. Pract Radiat Oncol. 2016;6(5):149. https://doi.org/10.1016/j.prro.2 016.01.004 Accessed 26 Apr 2018.

143. Nelson RA, Lai LL. Elevated risk of human papillomavirus-related second cancers in survivors of anal canal cancer. Cancer. 2017;123(20):4013-21. https://doi.org/10.1002/cncr.30828 Accessed 27 Nov 2018.

144. Chaturvedi AK, Engels EA, Gilbert ES, et al. Second cancers among 104,760 survivors of cervical cancer: Evaluation of long-term risk. J Natl Cancer Inst. 2007;99(21):1634-43. https://doi.org/10.1093/jnci/djm201 Accessed 27 Nov 2018
145. Shah BK, Budhathoki N. Second primary malignancy in anal carcinoma--A US population-based study. Anticancer Res. 2015;35(7):4131-4 https://www. ncbi.nlm.nih.gov/pubmed/26124366.

146. Gilbert DC, Wakeham K, Langley RE, Vale CL. Increased risk of second cancers at sites associated with HPV after a prior HPV-associated malignancy, a systematic review and meta-analysis. Br J Cancer. 2019;120(2): 256-68. https://doi.org/10.1038/s41416-018-0273-9 https://www.ncbi.nlm. nih.gov/pubmed/30482913.

147. International Anal Neoplasia Society. HRA course overview. IANS Web site https://ians.wildapricot.org/HRA-Course-Overview. Updated 2018.

148. Sodergren SC, Johnson CD, Gilbert A, et al. Phase I-III development of the EORTC QLQ-ANL27, a health-related quality of life questionnaire for anal cancer. Radiother Oncol. 2018;126(2):222-8. https://doi.org/10.1016/j. radonc.2017.11.018 https://www.sciencedirect.com/science/article/pii/S016 7814017327354

\section{Publisher's Note}

Springer Nature remains neutral with regard to jurisdictional claims in published maps and institutional affiliations.

Ready to submit your research? Choose BMC and benefit from:

- fast, convenient online submission

- thorough peer review by experienced researchers in your field

- rapid publication on acceptance

- support for research data, including large and complex data types

- gold Open Access which fosters wider collaboration and increased citations

- maximum visibility for your research: over $100 \mathrm{M}$ website views per year

At BMC, research is always in progress.

Learn more biomedcentral.com/submissions 